\title{
Analysis of the Trend of Students' Achievement in Physics in West Africa Examination Council Organized Senior Secondary School Certificate Examination
}

\author{
Christogonus Nweke (Ph.D) ${ }^{1} \quad$ Emmanuel Ogbaga (Ph.D) ${ }^{1} \quad$ Rev. Sis. Ikenga Catherine Ngozi ${ }^{2}$ \\ 1.Department of Science Education, Ebonyi State University, Abakaliki \\ 2.Department of Educational Foundation, Ebonyi State University, Abakaliki
}

\begin{abstract}
This study is on analysis of the trend of students' achievement in physics in West African Examination Council organized Senior School Certificate Examination (SSCE). The study methodically investigated the trend of students' achievement in physics in WASSCE in the South east geopolitical zone of Nigeria between 2015 and 2017 years. To conduct the study, the researchers adopted a survey research design of ex-post-facto method. Specifically the study carefully analysed students' academic achievement in physics within the period of coverage. The sample of the study is made up of all physics students who sat for physics in SSCE in the zone within the period with a total population of one hundred and eleven thousand and twenty seven (111027) students. Four (4) research questions and eight (8) hypotheses guided the study. From the findings of the study, it was seen that while Abia state presented the least number of students entry, Imo state presented the highest number of students' entry in the zone in physics in SSCE. Secondly, the zone recorded more than average mean percentage achievement in the high grade pass. Ebonyi state was seen to have recorded the least average percentage achievement and as well recorded the highest number of F9 (failure) grade within the period in the zone. On the basis of the findings, it was recommended that states should continue to support the teaching of physics in schools with provision of funds in their budgets and ensure its release for science programme implementation. It was also recommended that qualified physics teachers should be attracted to teach physics in schools. Finally, in-service training and other incentives should be provided to physics teachers to motivate them.
\end{abstract}

DOI: $10.7176 / \mathrm{JEP} / 12-36-04$

Publication date: December $31^{\text {st }} 2021$

\section{INTRODUCTION}

The potential of a nation's technological and scientific advancement is largely measured by the scholastic achievement of the citizenry in the sciences at the early stage of the citizenry's educational pursuit. This is because scientific and technologies breakthrough is the engine room for scientific and technological advancement. The scientific and technological breakthrough is anchored on the level of mastery of the skills in doing science and the knowledge acquired from it. It is pertinent to note that it is in line with this view that gave rise to the assertion by Sakiyo and Badau (2015) that strides in science and technology were the catalysts in the development of many countries in the world.

If such assertion is anything to go by, one can infer and subsequently generalize that the stride a nation will make in science and technology can be effectively measured with high accuracy through the determination of the level of achievement of the nation's youngsters in the sciences. This is because these youngsters will drive the future scientific and technological programmes and advancement of the country. This justifies the inquiry into how well students perform in competitive science examinations, mostly in examinations organized by bodies such as WAEC that has both national and international reckoning.

Apparently, the interest and concerns shown by the general public on students' performance and eventual achievement in science subjects are that student's knowledge and mastery of the sciences are panacea and indispensible tools in the search for the appropriate solutions to the daunting socio-economic problems of any society. Hence, societies and individuals cannot relegate to the background, the study of sciences, nor, shift attention from it, neither will they alienable themselves from concerns about the performance of students in sciences. This is the case as it has been noted that science is inevitable because the contemporary society is controlled by science and technology (Ademola; Olufunke, and Amoke, 2013). Science as a body of knowledge comprised of some core subjects.

Physics is one of the three core science subjects studied in the senior secondary schools in Nigeria (FRN: 2013). Other core sciences studied in the senior secondary school are Chemistry and Biology (FRN: 2013; Mekonnen, 2014). Physics as a science subject contributes to the deep understanding of the concepts of the sciences. Infact according to Aina (2014) physics is the basic index in understanding the complexities of modern technologies. This suffices that poor or inadequate knowledge of physics and the lack of applications of the principles of it impinges on the scientific and technological advancement of a society. This is because without physics, technological and scientific culture cannot really take root (Otuka, 1985). To this effect, physics is 
described by some education science researchers as a fulcrum subjects among the sciences that requires special attention (Ibe; Onah; Umahi; Ugwuona, Ekpe, and Nnachi, 2013). This means that for a nation's search for scientific and technological solutions to the socio-economic problems to be effective, such a nation must pay special attention to the study of physics and such attention should transcend the ordinary but should also require systematic and conscious deliberate monitoring of students' scholastic achievement in physics as a subject of study. This will ensure that adequate actions to mitigate lapses as may be appropriate are taken at the right time. This is because of the link between students' understanding of physics to the attainment of the S\&T goals of the country.

Academic performance/achievement has been described as a scholastic standing of a student at any given moment (Adeyemi 2011, Mekonnen, 2014). The scholastic standing itself is directly linked to the academic performance of such student. The scholastic standing is described by Adeyemi (2011) as the grades obtained in a course or group of courses by a student. The grade obtained by a student measures how well or otherwise a student has learned a course or group of courses in which she/he obtained the grade. Furthermore, it is the basis of measuring the effectiveness of the teaching that takes place in schools. It forms the yardstick for sustaining or modifying and in some cases changing the educational policy of a nation, as it is the output of the educational system. Achievement or performance is the measure of school output (Adeyemi 2011). The grades obtained by students is an important variable which education stakeholders are interested in (Nweke, 2021) and has always been of great concern to parents/guardians throughout the world (Alaka and Obadara, 2013).

Furthermore, the interest shown by stakeholders on scholastic achievement of students rests on the fact that it provides feedback to parents/guardians on the academic progress of children/wards. It also provides information to the general public, employers of labour, and institutions of higher learning on how much a student has attained the learning goals clearly defined in the educational curriculum. It further provides information on the academic abilities of students and what they are capable of learning in the future based on what they have already learned. The scholastic achievement of students is determined through test/examination which the students take in the course of learning or through a summative test/examination at the end of the course. It is also sometimes determined through the combination of continuous testing and end of programme summative assessment.

Most often, the testing instrument and the processes are designed and administered by professional examination bodies like WAEC. This is to ensure that the testing procedure and the outcome meet set criterion defined by the policy. These professional testing or examination bodies report students' scholastic performance in grade points, rather than raw score form. The grading of students in the entire SSCE subjects in Nigeria by WAEC is that $A_{1}$ to $B_{3}$ represent the distinction grades. The credit grades are represented by $C_{4}$ to $C_{6}$. The ordinary pass grades are represented by $\mathrm{D}_{7}$ to $\mathrm{E}_{8}$, while the $\mathrm{F}_{9}$ grade represents failure (WAEC, 2019).

Generally, the acceptable grades range from the distinction to the credit grades. These are the grades which institutions of higher learning accept as qualification by students to apply for further studies. Those grades of scores are hereby referred in this study as the high grade scores, while D7 to E8 are referred to as low grades. If a high proportion of physics test takers in the WASSCE are unable to obtain those acceptable high grades, in a particular year or period, there is always public outcry that students have performance poorly. Such poor performances in physics portent bleak future for any nation's quest for S \& T advancement.

Regrettably, despite the important roles that physics plays in the S \& $\mathrm{T}$ advancement in Nigeria, there has been reported cases that Nigerian students perform poorly in physics in competitive examinations. For instance, Nwankwo and Madu (2014) had lamented that in Nigeria, between 2005 and 2010, on average, less than 30\% of the students who registered for WAEC entered for physics; out of these, only $40 \%$ passed at the credit level. Further insight on the poor performances of students in physics were given by Mekonnen (2014) when he stated that studies have revealed that the academic performances of Nigerian students in ordinary level physics were generally and consistently poor over the years. The causes of the poor performances were listed to include: the way physics in particular is taught in the secondary school (Ogunleye and Lasis, 2008); application of didactic approaches such as lecture method, and distorted guided inquiry method (Nwankwo and Madu, 2014); nature of physics and the parental educational background (Mekonnen, 2014); inadequate laboratory equipment/facilities in our schools (Onah and Ugwu, 2010). It was based on the importance of physics which is predicated on its enormous contribution to the understanding of science, and its further contribution to the advancement in science and technology and the growing concern on the poor achievement of students in physics at the SSCE level in Nigeria, that prompted this study which is titled the analysis of the trend of students' achievement in physics in the West African Senior Secondary School Certificate Examination. The study is centered in South East geopolitical zone of Nigeria.

\section{Statement of Problem}

In Nigeria, there is a growing concern that the number of students that study and sit for physics in SSCE organized by WAEC has been declining, and the performance of those who sat for physics in the WASSCE is poor. It is based on this growing concern on the poor students' scholastic achievement in physics, that prompted this study. The study equally investigated the relative performance of all states in southeast geopolitical zone in physics in 
the SSCE organized by WAEC within the study period.

\section{Methodology}

This study on the analysis of the trend of students' achievement in physics in WASSCE adopted descriptive survey research design. Specifically ex-post facto survey was the design of interest adopted. The data that were analyzed were collected from WAEC official records. The population of the study comprised of all the results of students in public schools that sat for physics in SSCE organized by WAEC between 2015 and 2017 academic year in the south east geopolitical zone.

The sample of the study is the total number of students that sat for physics in WASSCE in public school between 2015 to 2017 from all the states in the south east geopolitical zone.

The summary of the result of students' achievement in physics in WASSCE between 2015 and 2017 were officially obtained from WAEC. Based on the classification of the grades that students obtained in the examination by WAEC, the analysis was carried out. Chisquare was used to analyse the data in order to answer the hypothesis while the research questions were answered based on data analysis which were done using percentages and frequency counts.

\section{Research Questions}

1. What is the percentage entry of students per state per year in physics out of the zonal entry in south east geopolitical zone between 2015 - 2017?

2. What are the mean percentage achievements of students in each grade between 2015 to 2017 in the zone?

3. What are the states failure rates per year in physics between 2015 and 2017 in South East geopolitical zone?

4. What are the students' average percentage achievement rates in physics in WASSCE in each of the five states in the zone?

\section{Hypotheses}

Ho1: There is no statistical significance difference in the mean academic achievement of physics students in WASSCE in 2015 in South East geopolitical zone.

Ho2: There is no statistical significance difference in the mean academic achievement of students in physics in SSCE organized by WAEC in 2016 in South East geopolitical zone.

Ho3: There is no statistical significant difference in the mean percentage students' achievement scores in physics in SSCE organized by WAEC in 2017 in the five states of South East Geopolitical Zone.

Ho4: The percentage mean achievement scores of physics students in Ebonyi State in SSCE organized by WAEC between 2015 to 2017 is not statistically significant.

Hos: The mean achievement scores of physics students in Enugu State in SSCE organized by WAEC between 2015 and 2017 is not statistically significant.

Ho6: The percentage mean achievement scores of physics students in Abia State in SSCE organized by WAEC between 2015 and 2017 is not statistically significant.

Ho7: The percentage mean achievement scores of physics students in Imo State in SSCE organized by WAEC between 2015 and 2017 is not statistically significant.

Hos: The percentage mean achievement scores of physics students in Anambra State in SSCE organized by WAEC between 2015 and 2017 is not statistically significant.

\section{Results}

\section{Research Question I}

What is the percentage students' entry per state per year out of the total zonal entry in physics in the South East geopolitical zone in the SSCE organized by WAEC between 2015 and 2017 ?

\begin{tabular}{lllllll}
\hline Year/State & Abia & Anambra & Ebonyi & Enugu & Imo & Total \\
\hline \multirow{2}{*}{2015} & 4167 & 4912 & 4486 & 11198 & 11669 & 36458 \\
& $11.4 \%$ & $13.5 \%$ & $12.3 \%$ & $30.7 \%$ & $32 \%$ & 36331 \\
2016 & 4283 & 5446 & 4975 & 10931 & 10696 & 38258 \\
& $11.7 \%$ & $14.9 \%$ & $13.7 \%$ & $30 \%$ & $29 \%$ & 11991 \\
2017 & 4194 & 5974 & 5272 & 10827 & $31.3 \%$ & \\
\hline
\end{tabular}

Source: WAEC, Yaba Lagos (2019).

The displayed results in table I showed the \% students entry per year per state based on the total zonal entry in physics in SSCE organized by WAEC in south east geopolitical zone between 2015 and 2017. Based on the table, Abia State in 2015 had $11.4 \%$, in 2015 it was $11.7 \%$ while in 2017 , it was $11 \%$ respectively. For Anambra State, it was 2015 (13.5\%); 2016 (14.9\%) and 2017 (15.6\%). For Ebonyi State, it was 2015 (12.3\%); 2016 (13.7\%) 
and 2017 (13.8\%). Enugu State, 2015 (30.7\%); 2016 (30\%), 2017 (28.3\%). Imo State, 2015 (32\%), 2016 (29\%) and $2017(31.2 \%)$ respectively. Hence, it can be seen that Enugu and Imo States have the highest entries while Abia has the lowest \% entry in the zone within the period referred.

\section{Research Question 2}

What are the mean \% achievement score of students in each grade between 2015 and 2017 in the south east geopolitical zone?

Table 2a: Percentage scores and number of students and the grades obtained in physics in SSCE in 2015

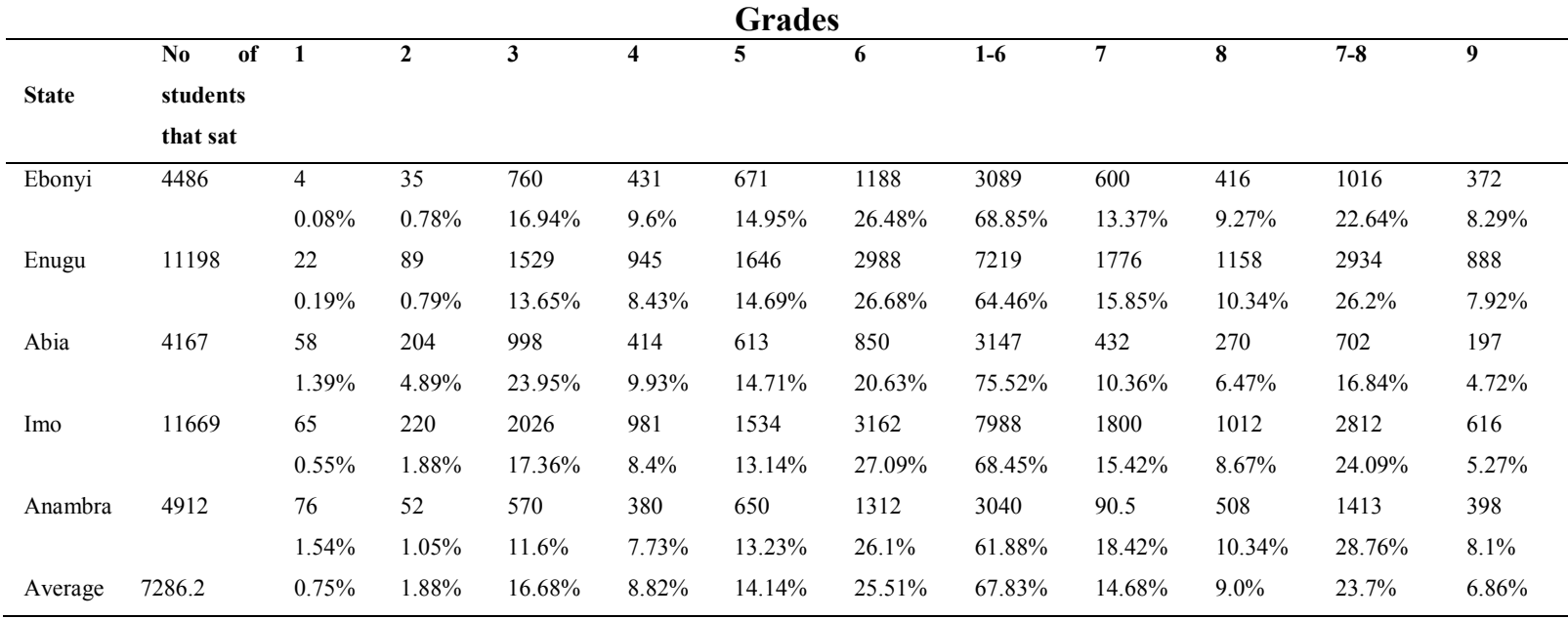

Source: WAEC, Yaba Lagos (2019).

Table 2b: Percentage score and No of students and the Grades obtained in Physics in SSCE in 2016

\begin{tabular}{|c|c|c|c|c|c|c|c|c|c|c|c|c|}
\hline \multicolumn{13}{|c|}{ Grades } \\
\hline State & $\begin{array}{l}\text { No that } \\
\text { sat }\end{array}$ & 1 & 2 & 3 & 4 & 5 & 6 & $1-6$ & 7 & 8 & $7-8$ & 9 \\
\hline \multirow[t]{2}{*}{ Ebonyi } & 4975 & 58 & 128 & 1029 & 565 & 760 & 1165 & 3705 & 459 & 331 & 790 & 440 \\
\hline & & $1.16 \%$ & $2.57 \%$ & $20.68 \%$ & $11.35 \%$ & $15.27 \%$ & $23.41 \%$ & $74.47 \%$ & $9.22 \%$ & $6.65 \%$ & $15.87 \%$ & $8.84 \%$ \\
\hline \multirow[t]{2}{*}{ Enugu } & 10931 & 122 & 381 & 3379 & 1319 & 1714 & 2345 & 9260 & 906 & 430 & 1336 & 247 \\
\hline & & $1.11 \%$ & $3.48 \%$ & $30.91 \%$ & $12.06 \%$ & $15.68 \%$ & $21.45 \%$ & $84.71 \%$ & $8.28 \%$ & $3.93 \%$ & $12.22 \%$ & $2.25 \%$ \\
\hline \multirow[t]{2}{*}{ Abia } & 4283 & 31 & 172 & 1048 & 487 & 589 & 903 & 3230 & 355 & 220 & 575 & 168 \\
\hline & & $0.72 \%$ & $4.01 \%$ & $24.46 \%$ & $11.37 \%$ & $13.75 \%$ & $21.08 \%$ & $75.41 \%$ & $8.28 \%$ & $5.13 \%$ & $13.42 \%$ & $3.92 \%$ \\
\hline \multirow[t]{2}{*}{ Imo } & 10696 & 160 & 410 & 3103 & 1262 & 1605 & 2260 & 8800 & 901 & 394 & 1295 & 169 \\
\hline & & $1.49 \%$ & $3.83 \%$ & $29.01 \%$ & $11.79 \%$ & $15 \%$ & $21.12 \%$ & $82.27 \%$ & $8.42 \%$ & $3.68 \%$ & $12.1 \%$ & $1.58 \%$ \\
\hline \multirow[t]{2}{*}{ Anambra } & 5446 & 66 & 156 & 1439 & 693 & 1003 & 1257 & 4614 & 446 & 194 & 640 & 154 \\
\hline & & $1.21 \%$ & $2.86 \%$ & $26.42 \%$ & $12.72 \%$ & $18.41 \%$ & $23.08 \%$ & & $8.18 \%$ & $3.56 \%$ & $11.75 \%$ & $2.82 \%$ \\
\hline Average & 7266.2 & $1.13 \%$ & $3.34 \%$ & $26.29 \%$ & $11.83 \%$ & $15.62 \%$ & $22.02 \%$ & $80.31 \%$ & $8.47 \%$ & $4.59 \%$ & $13.08 \%$ & $3.88 \%$ \\
\hline
\end{tabular}

Source: WAEC, Yaba Lagos (2019). 
Table 2c: Percentage score and number of students and grade obtained in Physics in SSCE in 2017

\begin{tabular}{|c|c|c|c|c|c|c|c|c|c|c|c|c|}
\hline \multicolumn{13}{|c|}{ Grades } \\
\hline State & $\begin{array}{l}\text { No of } \\
\text { students } \\
\text { that sat }\end{array}$ & 1 & 2 & 3 & 4 & 5 & 6 & $1-6$ & 7 & 8 & $7-8$ & 9 \\
\hline \multirow[t]{2}{*}{ Ebonyi } & 5272 & 10 & 71 & 584 & 428 & 718 & 1642 & 3453 & 869 & 549 & 1418 & 374 \\
\hline & & $0.18 \%$ & $1.34 \%$ & $11.07 \%$ & $8.11 \%$ & $13.61 \%$ & $31.14 \%$ & $65.49 \%$ & $16.48 \%$ & $10.41 \%$ & $26.83 \%$ & $7.09 \%$ \\
\hline \multirow[t]{2}{*}{ Enugu } & 10827 & 17 & 153 & 1712 & 743 & 1220 & 2757 & 6602 & 1981 & 1295 & 3276 & 740 \\
\hline & & $0.15 \%$ & $1.41 \%$ & $15.81 \%$ & $6.86 \%$ & $11.26 \%$ & $25.46 \%$ & $60.97 \%$ & $18.29 \%$ & $11.96 \%$ & $30.25 \%$ & $6.83 \%$ \\
\hline \multirow[t]{2}{*}{ Abia } & 4194 & 10 & 44 & 482 & 268 & 516 & 1088 & 2408 & 690 & 528 & 1218 & 385 \\
\hline & & $0.23 \%$ & $1.04 \%$ & $11.49 \%$ & $6.39 \%$ & $12.3 \%$ & $25.94 \%$ & $57.41 \%$ & $16.45 \%$ & $12.58 \%$ & $29.04 \%$ & $9.17 \%$ \\
\hline \multirow[t]{2}{*}{ Imo } & 11991 & 17 & 154 & 1225 & 944 & 1578 & 3018 & 6936 & 1856 & 1755 & 3611 & 1183 \\
\hline & & $0.14 \%$ & $1.28 \%$ & $10.21 \%$ & $7.87 \%$ & $13.15 \%$ & $25.16 \%$ & $57.84 \%$ & $15.47 \%$ & $14.63 \%$ & $30.11 \%$ & $9.86 \%$ \\
\hline \multirow[t]{2}{*}{ Anambra } & 5974 & 145 & 132 & 973 & 411 & 801 & 1485 & 3947 & 995 & 678 & 1673 & 350 \\
\hline & & $2.42 \%$ & $2.2 \%$ & $16.28 \%$ & $6.87 \%$ & $13.4 \%$ & $24.85 \%$ & $66.06 \%$ & $16.65 \%$ & $11.34 \%$ & $28 \%$ & $5.85 \%$ \\
\hline Average & 7651.6 & $0.62 \%$ & $1.45 \%$ & $12.97 \%$ & $7.22 \%$ & $12.74 \%$ & $26.51 \%$ & $61.55 \%$ & $16.66 \%$ & $12.18 \%$ & $28.84 \%$ & $7.76 \%$ \\
\hline
\end{tabular}

Source: WAEC, Yaba Lagos (2019).

As displayed in tables $2 \mathrm{a}-\mathrm{c}$, the mean \% grades obtained by students in physics in SSCE organized by WAEC in south east geopolitical zone are as follows; in $2015 \mathrm{Ai}(0.75 \%) ; \mathrm{B}_{2}(1.86 \%) ; \mathrm{B}_{3}(16.68 \%) ; \mathrm{C}_{4}(8.82 \%) ; \mathrm{C}_{5}$ $(14.14 \%) ; \mathrm{C}_{6}(25.5 \%) \mathrm{E}_{7}(14.68 \%) ; \mathrm{E}_{8}(9 \%)$; and $\mathrm{F}_{9}(6.86 \%)$. In 2016, the average \% grades were $\mathrm{A}_{1}(1.13 \%), \mathrm{B}_{2}$ (3.34\%); $\mathrm{B}_{3}(26.29 \%) ; \mathrm{C}_{4}(11.83 \%) ; \mathrm{C}_{5}(15.62 \%) ; \mathrm{C}_{6}(22.07) \mathrm{E}_{7}(8.47 \%) ; \mathrm{E}_{8}(4.59 \%) ;$ and $\mathrm{F}_{9}(3.88 \%)$. In 2017 , the $\%$ mean distributions of students achievement in the zone were: $\mathrm{A}_{1}(0.062) ; \mathrm{B}_{2}(1.45 \%) ; \mathrm{B}_{3}(12.97 \%) ; \mathrm{C}_{4}$ (7.22\%); $\mathrm{C}_{5}(12.74 \%) ; \mathrm{C}_{6}(26.51 \%) \mathrm{E}_{7}(16.66 \%) ; \mathrm{E}_{8}(12.18 \%)$ and $\mathrm{F}_{9}(7.76 \%)$. The table further showed that in $2015,67.83 \%$ of the students obtained high grade pass $\left(\mathrm{A}_{1}-\mathrm{C}_{6}\right)$, while $23.7 \%$ obtained low grade pass $\left(\mathrm{E}_{7}-\mathrm{E}_{8}\right)$. In $2016,80.31 \%$ of the students obtained high grade pass while $13.08 \%$ obtained low grade pass. Finally in 2017 , $61.55 \%$ obtained high grade pass while $28.84 \%$ obtained low grade pass. Based on the results for the three years, students had the best results in physics in 2016 while their results in 2015 and 2017 were almost at per.

\section{Research Question 3}

What are the states' students' failure rates per year between 2015 to 2017 in physics in SSCE organized by WAEC in South East geopolitical zone?

Table 3. Showing students' failure rates by states in physics in the SSCE organized by WAEC between 2015 and 2017 in the southeast zone.

\begin{tabular}{lllll}
\hline S/NO & Year/State & $\mathbf{2 0 1 5}$ & $\mathbf{2 0 1 6}$ & $\mathbf{2 0 1 7}$ \\
\hline 1 & Ebonyi & $372(8.296)$ & $440(8.84 \%)$ & $374(7.09 \%)$ \\
2 & Enugu & $888(7.92 \%)$ & $247(2.25 \%)$ & $740(6.8 \%)$ \\
3 & Abia & $197(4.72 \%)$ & $168(3.92 \%)$ & $385(9.17 \%)$ \\
4 & Imo & $616(5.27 \%)$ & $169(1.58 \%)$ & $1183(9.86 \%)$ \\
5 & Anambra & $398(8.1 \%)$ & $154(2.82 \%)$ & $350(5.85 \%)$ \\
\hline
\end{tabular}

Source: WAEC, Yaba Lagos (2019).

As shown in table 3, the students' failure rates per state in physics in SSCE organized by WAEC in Southeast zone between 2015 and 2017 where Ebonyi, 2015 (8:29\%); 2016 (8:84\%) and 2017(7:09\%). Enugu State, 2015(7.92\%); 2016(2:25\%) and 2017(76.92\%). Abia State, 2015(4.72\%); $2016(3.92 \%)$ and $2017(9.17 \%)$. Imo State, 2015 (5.27\%); 2016 (1.58\%) and 2017 (9.86\%). Anambra state, 2015 (8.1\%); $2016(2.82 \%)$ and 2017 $(5.85 \%)$. These show that Ebonyi State recorded the highest failure rates within the period in the zone.

\section{Research Question 4}

What are the average percentage students' achievement rates in Physics in SSCE organized by WAEC by states in South east geopolitical zone between 2015 and 2017 ? 
Table 4a. Percentage score and number of students with grades obtained in physics in WASSCE between 2015 to 2017 in Ebonyi State.

\begin{tabular}{|c|c|c|c|c|c|c|c|c|c|c|c|c|}
\hline \multicolumn{13}{|c|}{ Grades } \\
\hline Year & $\begin{array}{l}\text { No. of } \\
\text { student } \\
\text { that sat }\end{array}$ & 1 & 2 & 3 & 4 & 5 & 6 & $1-6$ & 7 & 8 & $7-8$ & 9 \\
\hline \multirow[t]{2}{*}{2015} & 4486 & 4 & 35 & 760 & 431 & 671 & 1188 & 3089 & 600 & 416 & 1016 & 372 \\
\hline & & $0.08 \%$ & $0.78 \%$ & $16.94 \%$ & $9.6 \%$ & $14.95 \%$ & $26.48 \%$ & 68.85 & $13.37 \%$ & $9.27 \%$ & $22.16 \%$ & $8.29 \%$ \\
\hline \multirow[t]{2}{*}{2016} & 4975 & 58 & 128 & 1029 & 565 & 760 & 1165 & 3705 & 459 & 331 & 790 & 440 \\
\hline & & $1.16 \%$ & $2.51 \%$ & $20.68 \%$ & $11.35 \%$ & $15.27 \%$ & $23.41 \%$ & $74.47 \%$ & $9.23 \%$ & $6.65 \%$ & $15.81 \%$ & $8.84 \%$ \\
\hline \multirow[t]{2}{*}{2017} & 5272 & 10 & 71 & 584 & 428 & 718 & 1642 & 34.58 & 869 & 549 & 1418 & 374 \\
\hline & & $0.18 \%$ & $1.34 \%$ & $11.07 \%$ & $8.11 \%$ & $13.61 \%$ & $31.14 \%$ & $65.49 \%$ & $16.48 \%$ & $10.41 \%$ & $26.83 \%$ & $7.09 \%$ \\
\hline \multicolumn{2}{|c|}{ Average \% } & $0.47 \%$ & $1.56 \%$ & $16.23 \%$ & $9.7 \%$ & $14.61 \%$ & $27 \%$ & $69.6 \%$ & $13.0 \%$ & $8.8 \%$ & $21.8 \%$ & $6.1 \%$ \\
\hline
\end{tabular}

Source: WAEC, Yaba Lagos (2019).

Table 4b. Percentage score and number of students with grades obtained in physics in WASSCE between 2015 to 2017 in Enugu State.

\begin{tabular}{|c|c|c|c|c|c|c|c|c|c|c|c|c|}
\hline \multicolumn{13}{|c|}{ Grades } \\
\hline Year & $\begin{array}{l}\text { No. of } \\
\text { student } \\
\text { that sat }\end{array}$ & 1 & 2 & 3 & 4 & 5 & 6 & $1-6$ & 7 & 8 & $7-8$ & 9 \\
\hline \multirow[t]{2}{*}{2015} & 11198 & 22 & 89 & 1529 & 945 & 1646 & 2988 & 7219 & 1776 & 1158 & 2934 & 888 \\
\hline & & $0.19 \%$ & $0.79 \%$ & $13.65 \%$ & $8.45 \%$ & $14.69 \%$ & $26.68 \%$ & $64.46 \%$ & $15.85 \%$ & $10.34 \%$ & $26.2 \%$ & $7.92 \%$ \\
\hline \multirow[t]{2}{*}{2016} & 10931 & 122 & 381 & 3379 & 1319 & 1714 & 2345 & 9260 & 906 & 430 & 1336 & 247 \\
\hline & & $1.11 \%$ & $3.48 \%$ & $30.91 \%$ & $20.06 \%$ & $15.68 \%$ & $21.45 \%$ & $84.71 \%$ & $8.28 \%$ & $3.93 \%$ & $12.22 \%$ & $2.25 \%$ \\
\hline \multirow[t]{2}{*}{2017} & 10827 & 17 & 153 & 1712 & 743 & 1220 & 2756 & 6602 & 1981 & 1295 & 3276 & 740 \\
\hline & & $0.15 \%$ & $1.41 \%$ & $15.81 \%$ & $6.86 \%$ & $11.26 \%$ & $25.46 \%$ & $60.97 \%$ & $1829 \%$ & $11.96 \%$ & $30.25 \%$ & $6.83 \%$ \\
\hline $\begin{array}{l}\text { Average } \\
10985\end{array}$ & $\%$ & $0.5 \%$ & $1.9 \%$ & $20.1 \%$ & $9.1 \%$ & $13.9 \%$ & $24.5 \%$ & $70 \%$ & $14.1 \%$ & $8.7 \%$ & $22.9 \%$ & $5.7 \%$ \\
\hline
\end{tabular}

Source: WAEC, Yaba Lagos (2019).

Table 4c. Percentage score and number of students with grades obtained in physics in WASSCE between 2015 to 2017 in Abia State.

\begin{tabular}{|c|c|c|c|c|c|c|c|c|c|c|c|c|}
\hline \multicolumn{13}{|c|}{ Grades } \\
\hline Year & $\begin{array}{l}\text { No. of } \\
\text { student } \\
\text { that sat }\end{array}$ & 1 & 2 & 3 & 4 & 5 & 6 & $1-6$ & 7 & 8 & $7-8$ & 9 \\
\hline \multirow[t]{2}{*}{2015} & 4167 & 58 & 204 & 998 & 414 & 613 & 850 & 3147 & 432 & 270 & 702 & 197 \\
\hline & & $1.39 \%$ & $4.89 \%$ & $23.95 \%$ & $9.93 \%$ & $14.71 \%$ & $20.63 \%$ & $75.52 \%$ & $10.36 \%$ & $6.47 \%$ & $16.84 \%$ & $4.72 \%$ \\
\hline \multirow[t]{2}{*}{2016} & 4283 & 31 & 172 & 1048 & 487 & 589 & 903 & 3230 & 355 & 220 & 575 & 168 \\
\hline & & $0.72 \%$ & $4.01 \%$ & $24.46 \%$ & $11.37 \%$ & $13.75 \%$ & $21.08 \%$ & $75.41 \%$ & $8.28 \%$ & $5.13 \%$ & $13.42 \%$ & $3.92 \%$ \\
\hline \multirow[t]{2}{*}{2017} & 4194 & 10 & 44 & 482 & 268 & 516 & 1088 & 2408 & 690 & 528 & 1218 & 385 \\
\hline & & $0.23 \%$ & $1.04 \%$ & $11.49 \%$ & $6.39 \%$ & $12.3 \%$ & $25.94 \%$ & $57.41 \%$ & $16.45 \%$ & $12.58 \%$ & $29.04 \%$ & $9.17 \%$ \\
\hline \multicolumn{2}{|c|}{ Average 4215} & $0.78 \%$ & $3.3 \%$ & $19.9 \%$ & $9.2 \%$ & $13.6 \%$ & $22.6 \%$ & $69.4 \%$ & $11.7 \%$ & $8.1 \%$ & $19.8 \%$ & $5.9 \%$ \\
\hline
\end{tabular}

Source: WAEC, Yaba Lagos (2019).

Table 4d. Percentage score and number of students with grades obtained in physics in WASSCE between 2015 to 2017 in Imo State.

\begin{tabular}{|c|c|c|c|c|c|c|c|c|c|c|c|c|}
\hline \multicolumn{13}{|c|}{ Grades } \\
\hline Year & $\begin{array}{l}\text { No. of } \\
\text { student } \\
\text { that sat }\end{array}$ & 1 & 2 & 3 & 4 & 5 & 6 & $1-6$ & 7 & 8 & $7-8$ & 9 \\
\hline \multirow[t]{2}{*}{2015} & 11669 & 65 & 220 & 2026 & 981 & 1534 & 3162 & 7988 & 1800 & 1012 & 2812 & 616 \\
\hline & & $0.55 \%$ & $11.88 \%$ & $17.36 \%$ & $8.4 \%$ & $13.14 \%$ & $27.09 \%$ & $68.45 \%$ & $15.42 \%$ & $8.67 \%$ & $24.09 \%$ & $5.27 \%$ \\
\hline \multirow[t]{2}{*}{2016} & 10696 & 160 & 410 & 3103 & 1262 & 1605 & 2260 & 8800 & 901 & 394 & 1295 & 169 \\
\hline & & $1.49 \%$ & $3.83 \%$ & $29.01 \%$ & $11.79 \%$ & $15 \%$ & $21.12 \%$ & $82.27 \%$ & $8.42 \%$ & $3.68 \%$ & $12.1 \%$ & $1.58 \%$ \\
\hline \multirow[t]{2}{*}{2017} & 11991 & 17 & 154 & 1225 & 944 & 1578 & 3018 & 6936 & 1856 & 1755 & 3611 & 1183 \\
\hline & & $0.14 \%$ & $1.28 \%$ & $10.21 \%$ & $7.87 \%$ & $13.15 \%$ & $25.16 \%$ & $57.84 \%$ & $15.47 \%$ & $14.63 \%$ & $30.11 \%$ & $9.86 \%$ \\
\hline \multicolumn{2}{|c|}{ Average 11452} & $0.73 \%$ & $5.7 \%$ & $18.9 \%$ & $9.4 \%$ & $13.8 \%$ & $24.5 \%$ & $69.5 \%$ & $13.1 \%$ & $9 \%$ & $22.1 \%$ & $5.6 \%$ \\
\hline
\end{tabular}

Source: WAEC, Yaba Lagos (2019). 
Table 4e. Percentage score and number of students with grades obtained in physics in WASSCE between 2015 to 2017 in Anambra State.

\begin{tabular}{|c|c|c|c|c|c|c|c|c|c|c|c|c|}
\hline \multicolumn{13}{|c|}{ Grades } \\
\hline Year & $\begin{array}{l}\text { No. of } \\
\text { student that } \\
\text { sat }\end{array}$ & 1 & 2 & 3 & 4 & 5 & 6 & $1-6$ & 7 & 8 & $7-8$ & 9 \\
\hline \multirow[t]{2}{*}{2015} & 4912 & 76 & 52 & 570 & 380 & 650 & 1312 & 3040 & 905 & 503 & 1413 & 398 \\
\hline & & $1.54 \%$ & $1.06 \%$ & $11.6 \%$ & $7.73 \%$ & $13.23 \%$ & $26.7 \%$ & $61.88 \%$ & $18.42 \%$ & $10.34 \%$ & $28.76 \%$ & $8.1 \%$ \\
\hline \multirow[t]{2}{*}{2016} & 5446 & 66 & 156 & 1439 & 693 & 1003 & 1257 & 4614 & 446 & 194 & 640 & 154 \\
\hline & & $1.21 \%$ & $2.86 \%$ & $26.42 \%$ & $12.72 \%$ & $18.41 \%$ & $23.08 \%$ & $84.72 \%$ & $8.18 \%$ & $3.56 \%$ & $11.75 \%$ & $2.82 \%$ \\
\hline \multirow[t]{2}{*}{2017} & 5974 & 145 & 132 & 973 & 411 & 801 & 1485 & 3947 & 995 & 678 & 1673 & 350 \\
\hline & & $2.42 \%$ & $2.2 \%$ & $16.28 \%$ & $6.87 \%$ & $13.4 \%$ & $24.85 \%$ & $66.06 \%$ & $16.65 \%$ & $11.34 \%$ & $28 \%$ & $5.85 \%$ \\
\hline \multicolumn{2}{|c|}{ Average 5444} & $1.7 \%$ & $2.04 \%$ & $18.1 \%$ & $9.1 \%$ & $15 \%$ & $24.9 \%$ & $70.9 \%$ & $12.75 \%$ & $8.4 \%$ & $22.8 \%$ & $5.6 \%$ \\
\hline
\end{tabular}

Source: WAEC, Yaba Lagos (2019).

The results displayed in tables $4 \mathrm{a}$ - e shows the relative standing of the states in the zone in Physics in SSCE organized by WAEC between 2015 and 2017. Table 4a shows that the average percentage students' achievement in Ebonyi State for the three years were as follows, $\mathrm{A}_{1}(0.47), \mathrm{B}_{2}(1.56), \mathrm{B}_{3}(16.23), \mathrm{C}_{4}(9.7), \mathrm{C}_{5}(14.61), \mathrm{C}_{6}(27.0)$, $\mathrm{D}_{7}$ (13.0), $\mathrm{E}_{8}(8.8)$ and $\mathrm{F}_{9}(6.1)$. In table $4 \mathrm{~b}$ showed that Enugu state students' average percentage grade scores were $\mathrm{A}_{1}(0.5), \mathrm{B}_{2}$ (1.9), $\mathrm{B}_{3}(20.1), \mathrm{C}_{4}(9.1), \mathrm{C}_{5}$ (13.9), $\mathrm{C}_{6}(24.5), \mathrm{D}_{7}(14.1), \mathrm{E}_{8}(8.7)$ and $\mathrm{F}_{9}(5.7)$. Table 4c, the result contained showed that Abia state students' had average percentage grade scores of $\mathrm{A}_{1}(0.78), \mathrm{B}_{2}(3.3), \mathrm{B}_{3}(19.9)$, $\mathrm{C}_{4}$ (9.2), $\mathrm{C}_{5}$ (13.6), $\mathrm{C}_{6}(22.6), \mathrm{D}_{7}$ (11.7), $\mathrm{E}_{8}(8.1)$ and $\mathrm{F}_{9}$ (5.9). Table 4d showed that Imo state had the following average percentage grades for the three years, $\mathrm{A}_{1}(0.73), \mathrm{B}_{2}(5.7), \mathrm{B}_{3}(18.9), \mathrm{C}_{4}(9.4), \mathrm{C}_{5}(13.8), \mathrm{C}_{6}(24.5), \mathrm{D}_{7}$ (13.1), $\mathrm{E}_{8}$ (9.0) and $\mathrm{F}_{9}$ (5.6). For Anambra state, table 4e showed that they had $\mathrm{A}_{1}(1.7), \mathrm{B}_{2}(2.04), \mathrm{B}_{3}(18.1), \mathrm{C}_{4}(9.1), \mathrm{C}_{5}$ (15), $\mathrm{C}_{6}(24.9), \mathrm{D}_{7}(12.75), \mathrm{E}_{8}(8.4)$ and $\mathrm{F}_{9}(5.6)$

Further perusal through the tables showed that the average percentage achievement of states in high grade scores. The tables showed that Ebonyi state had 69.6\%, Enugu state had 70\%, Abia state (69.4\%), Imo state (69.5\%) while Anambra state had 70.9\%. For the low grade score category, Ebonyi state had 21.8\%, Enugu had 22.9\%, Abia 19.8\%, Imo 22.1\% and Anambra, 22.8\%. Based on these scores, it is seen that Anambra state had the highest average percentage high grade scores, followed by Abia state. On the low grade scores, Enugu state had the highest average percentage low grade scores, followed by Anambra state. Finally, Ebonyi state had the highest average percentage $\mathrm{F}_{9}$ score for the three years, followed by Abia state, while Anambra and Imo had the least average number of $\mathrm{F}_{9}$.

\section{Hypotheses}

Ho1: There is no statistical significant difference in the mean academic achievement of physics students in SSCE organized by WAEC in Southeast geopolitical zone in 2015.

To test this null hypothesis of no significance difference in the mean achievement scores of students in physics in WASSCE from the five states that make up the South east geopolitical zone, data on students' achievement scores for the years were collected officially from WAEC. The grades were classified into high grade, low grades and failure grade. The data of the high grade scores of the physics students from the five states were grouped together and a chi-square analysis was carried out on the data in order to determine whether the mean of the scores were significantly different.

Table 5a: Showing number of students that obtained high grade in physics in SSCE in 2015 in the five states in South East geopolitical zone.

\begin{tabular}{llllllll}
\multicolumn{7}{c}{ Grades } \\
\hline States & $\mathbf{1}$ & $\mathbf{2}$ & $\mathbf{3}$ & $\mathbf{4}$ & $\mathbf{5}$ & $\mathbf{6}$ & Total \\
\hline Ebonyi & 4 & 35 & 760 & 431 & 671 & 1188 & 3089 \\
Enugu & 22 & 89 & 1529 & 945 & 1646 & 2988 & 7219 \\
Abia & 58 & 204 & 998 & 414 & 613 & 850 & 3147 \\
Imo & 65 & 220 & 2026 & 981 & 1534 & 3162 & 7988 \\
Anambra & 76 & 52 & 570 & 380 & 650 & 1312 & 3040 \\
Total & 225 & 600 & 5883 & 3151 & 5114 & 9500 & 24483 \\
\hline
\end{tabular}

$\mathrm{P}<0.05$

Summary of chisquare table

\begin{tabular}{lllll}
\hline Total & Df & Calculated $\chi^{2}$ squared & Table $\chi^{2}$ squared & Decision rule \\
\hline 24483 & 20 & 800.79 & 31.4 & Reject \\
\hline
\end{tabular}

As indicated in table $5 \mathrm{a}$, the $\chi^{2}$ calculated value of 800.79 is higher than the table (critical) value of 31.4. Based on the decision rule, the null hypothesis of no significance difference is rejected. The researcher rather concludes that there is a significance difference in the mean achievement scores of students in physics in SSCE organized by WAEC in the South east geopolitical zone in 2015. 
Ho2: This is no statistical significance difference in the mean percentage students' achievement scores in physics in SSCE organized by WAEC in 2016 among the states in South east geopolitical zone.

To test this null hypothesis, the data on the achievement of students in physics from the five states in the zone were collected from WAEC. The data collected were classified into high grade scores, low grade scores and failure grade. The high grade scores were used for the analysis, since it is the grades that are considered as qualification for admission into higher institutions of learning and even employers of labour give priority to it. Chi-square analysis techniques was used to carry out the analysis of the data. The data were reported in frequency counts based on the number of students that obtained each grade in each state.

Table 5b. Showing number of students that obtained high grade scores in physics in SSCE in 2016 in the five states in South east zone.

\begin{tabular}{llllllll}
\hline States & $\mathbf{1}$ & $\mathbf{2}$ & $\mathbf{3}$ & $\mathbf{4}$ & $\mathbf{5}$ & $\mathbf{6}$ & Total \\
\hline Ebonyi & 58 & 128 & 1029 & 565 & 760 & 1165 & 3705 \\
Enugu & 122 & 381 & 3379 & 1319 & 1714 & 2345 & 9260 \\
Abia & 31 & 172 & 1048 & 487 & 589 & 903 & 3230 \\
Imo & 160 & 410 & 2103 & 1262 & 1605 & 2260 & 8800 \\
Anambra & 66 & 156 & 1439 & 693 & 1003 & 1257 & 4614 \\
Total & 437 & 1247 & 9998 & 4326 & 5671 & 7930 & 29609 \\
\hline
\end{tabular}

$\mathrm{P}<0.05$

Summary of chisquare table

\begin{tabular}{lllll}
\hline Total & df & Calculated $\chi^{2}$ square & Table $\chi^{2}$ square & Decision rule \\
\hline 29609 & 20 & 196.95 & 31.4 & Reject \\
\hline
\end{tabular}

As indicated in table $5 b$, the calculated chi-square value (196.95) is greater than the chi-square critical (table value) of (31.4). Based on the decision rule, the null hypothesis of no significance difference is rejected. The researchers rather conclude by stating that there is a significance difference in the mean percentage achievement scores of students who sat for physics in SSCE organized by WAEC in 2016 in the five states of South east geopolitical zone.

Ho3: There is no statistical significance difference in the mean percentage achievement scores in physics in SSCE organized by WAEC in 2017 in the five (5) states of South east geopolitical zones.

Table 5c. Showing number of students that obtained high grade scores in physics in SSCE organized by WAEC in 2017 in the five states in South east zones.

\begin{tabular}{llllllll}
\multicolumn{7}{c}{ Grades } \\
\hline States & $\mathbf{1}$ & $\mathbf{2}$ & $\mathbf{3}$ & $\mathbf{4}$ & $\mathbf{5}$ & $\mathbf{6}$ & Total \\
\hline Ebonyi & 10 & 71 & 584 & 428 & 718 & 1642 & 3453 \\
Enugu & 17 & 153 & 1712 & 743 & 1220 & 2757 & 6602 \\
Abia & 10 & 44 & 482 & 268 & 516 & 1088 & 2408 \\
Imo & 17 & 154 & 1225 & 944 & 1578 & 3018 & 6936 \\
Anambra & 145 & 132 & 973 & 411 & 801 & 1485 & 3947 \\
Total & 199 & 554 & 4976 & 2794 & 4833 & 9990 & 23346 \\
\hline P $<0.05$ & & & & & & & \\
\hline
\end{tabular}

$\mathrm{P}<0.05$

Summary table of Chi square

\begin{tabular}{lllll}
\hline Total & df & Calculated $\chi^{2}$ square & Table $\chi^{2}$ square & Decision rule \\
\hline 23346 & 20 & 501.15 & 31.4 & Reject \\
\hline
\end{tabular}

Based on the result shown on the table $5 \mathrm{~b}$ and the associated chisquare $\left(\chi^{2}\right)$ values $(501.15)$ which is greater than the critical (table) chi-square value of (31.4), the researchers therefore rejected the null hypothesis of no significant difference. Hence, the researchers rather stated that there is a statistical significance difference in the mean percentage achievement scores of students in physics in SSCE organized by WAEC in 2017 in the five states in South east geopolitical zone.

Ho4: The average percentage achievement scores of students in physics in SSCE organized by WAEC between 2015 and 2017 in Ebonyi state is not statistical significant.

To test this hypothesis, data on students' average \% achievement in physics in SSCE organized by WAEC between 2015 and 2017 were extracted from official document collected from WAEC. The extracted data were the high grade scores. This is because; it is the grades that institutions of higher learning consider as qualification for students' admission. Furthermore, parent and employers of labour also consider the same set of grades as acceptable pass mark. The extracted data were analyzed using the chi-square (Pearson)/ Procedure. The data were reported in frequency counts based on the number of students that obtained each grade. 
Table 5d. Showing number of students that obtained high grade scores in physics in SSCE organized by WAEC in Ebonyi State between 2015 and 2017.

\begin{tabular}{llllllll}
\multicolumn{7}{c}{ Grades } \\
\hline States & $\mathbf{1}$ & $\mathbf{2}$ & $\mathbf{3}$ & $\mathbf{4}$ & $\mathbf{5}$ & $\mathbf{6}$ & Total \\
\hline 2015 & 4 & 35 & 760 & 431 & 671 & 1188 & 3089 \\
2016 & 58 & 128 & 1029 & 565 & 760 & 1165 & 3705 \\
2017 & 10 & 71 & 584 & 428 & 718 & 1642 & 3453 \\
Total & 72 & 234 & 2373 & 1424 & 2149 & 3993 & 10247 \\
\hline $\mathrm{P}<0.05$ & & &
\end{tabular}

$\mathrm{P}<0.05$

Summary of Chi-square table

\begin{tabular}{lllll}
\hline Total & df & Calculated $\chi^{2}$ square & Table $\chi^{2}$ square & Decision rule \\
\hline 10247 & 10 & 357.8 & 18.307 & Reject \\
\hline
\end{tabular}

From the table $5 \mathrm{~d}$ and the table of chi-square summary, it is seen that the calculated chi-square 357.8 is greater than the chi-square critical (table) value of 18.307. This makes the researchers to reject the null hypothesis. Hence, the conclusion is that the mean percentage achievement scores of students in physics in Eboni state between 2015 and 2016 is statistically significant.

Ho5: The average percentage achievement score of students in physics in SSCE organized by WAEC in Enugu state between 2015 and 2017 is not statistically significant.

To test this hypothesis, data on students' mean percentage achievement scores in physics were extracted from documents officially obtained from WAEC. The data of interest was those of the students' high grade score. This is because they are the ones that qualify students to seek admission in institution of higher learning. Parents and employers of labour consider the high grade scores as good pass. Chi-square was used to analyze the extracted data. The data were reported in frequency counts based on the number of students that obtained each grade for each year.

Table 5e. Showing number of students that obtained high grade scores in physics in SSCE organized by WAEC in Enugu State from 2015 to 2017.

\begin{tabular}{llllllll}
\multicolumn{7}{c}{ Grades } \\
\hline States & $\mathbf{1}$ & $\mathbf{2}$ & $\mathbf{3}$ & $\mathbf{4}$ & $\mathbf{5}$ & $\mathbf{6}$ & Total \\
\hline 2015 & 22 & 89 & 1529 & 945 & 1646 & 2988 & 7219 \\
2016 & 122 & 381 & 3379 & 1319 & 1714 & 2345 & 9260 \\
2017 & 17 & 153 & 1712 & 743 & 1220 & 2757 & 6602 \\
Total & 161 & 623 & 6620 & 3007 & 4580 & 8090 & 23081 \\
\hline
\end{tabular}

$\mathrm{P}<0.05$

Summary of Chi-square table

\begin{tabular}{lllll}
\hline Total & Df & Calculated $\chi^{2}$ square & Table $\chi^{2}$ square & Decision rule \\
\hline 23081 & 10 & 1060.52 & 18.307 & Reject \\
\hline
\end{tabular}

Based on the result on table 5e and the associated summary of the table of chi-square, the calculated $\chi^{2}$ (1060.52) is greater than the table chisquare value (18.307). The researchers therefore reject the null hypothesis, and concluded that there is a significance difference in the average $\%$ achievement rates of students in physics in SSCE organized by WAEC in Enugu state between 2015 and 2017.

Ho6: The percentage mean achievement of students in physics in SSCE organized between 2015 and 2017 in Abia state is not statistically significant.

To test this null hypothesis, the data on the percentage mean achievement of students between 2015 and 2017 were extracted from the official records obtained from WAEC. The data of interest was only the high grade scores. This grades are the acceptable grades for admission into institution of higher learning. Parents and the general public also consider the high grades as good pass. The data were reported in frequency counts based on the number of students that got each grade each year. 
Table 5f. Showing number of students that obtained high grade scores in physics in SSCE organized by WAEC in Abia State between 2015 to 2017.

\begin{tabular}{llllllll}
\multicolumn{7}{c}{ Grades } \\
\hline States & $\mathbf{1}$ & $\mathbf{2}$ & $\mathbf{3}$ & $\mathbf{4}$ & $\mathbf{5}$ & $\mathbf{6}$ & Total \\
\hline 2015 & 58 & 204 & 998 & 414 & 613 & 850 & 3137 \\
2016 & 31 & 172 & 1048 & 487 & 589 & 903 & 3230 \\
2017 & 10 & 44 & 482 & 268 & 516 & 1088 & 2408 \\
Total & 99 & 420 & 2528 & 1169 & 1718 & 2841 & 8775 \\
\hline P $<0.05$ & & &
\end{tabular}

$\mathrm{P}<0.05$

Summary of Chi-square table

\begin{tabular}{lllll}
\hline Total & Df & Calculated $\chi^{2}$ square & Table $\chi^{2}$ square & Decision rule \\
\hline 8775 & 10 & 375.0 & 18.307 & Reject \\
\hline
\end{tabular}

Based on the result on table $5 \mathrm{f}$ and, the calculated $\chi^{2}$ (375.0) which is greater than the critical $\chi^{2}(18.307)$, the researchers therefore rejected the null hypothesis. The conclusion is that there is a significant difference in the percentage mean achievement of students in physics in SSCE between 2015 and 2017 in Abia state.

Ho7: The percentage mean achievement scores of physics students un Imo state in SSCE organized by WAEC between 2015 and 2017 is not statistically significant.

To test the null hypothesis data on students percentage mean achievement within the period were extracted from official records collected from WAEC. The emphasis on only the high grade is that they serve as qualification for admission for further studies. Parents and the general public equally consider them as an acceptable satisfactory pass.

Table 5g. Showing number of students that obtained high grade scores in physics in SSCE organized by WAEC in Imo State between 2015 to 2017.

\begin{tabular}{llllllll}
\multicolumn{8}{c}{ Grades } \\
\hline States & $\mathbf{1}$ & $\mathbf{2}$ & $\mathbf{3}$ & $\mathbf{4}$ & $\mathbf{5}$ & $\mathbf{6}$ & Total \\
\hline 2015 & 65 & 220 & 2026 & 981 & 1534 & 3162 & 7988 \\
2016 & 260 & 410 & 3103 & 1262 & 1605 & 2260 & 8800 \\
2017 & 27 & 154 & 1225 & 944 & 1579 & 3018 & 6936 \\
Total & 242 & 784 & 6354 & 3181 & 4717 & 8440 & 23724 \\
\hline
\end{tabular}

$\mathrm{P}<0.05$

Summary of Chi-square table

\begin{tabular}{lllll}
\hline Total & Df & Calculated $\chi^{2}$ score & Table $\chi^{2}$ square & Decision rule \\
\hline 23724 & 10 & 1095.8 & 18.307 & Reject \\
\hline
\end{tabular}

From the result on table $5 \mathrm{~g}$, the calculated $\chi^{2}(1095.8)$ is greater than the table (critical) $\chi^{2}(18.307)$. The researchers therefore reject the null hypothesis and then concluded that there is significant difference in the $\%$ mean achievement of students in physics in SSCE in Imo state between 2015 and 2017.

Hos: The percentage mean achievement of students in physics in SSCE organized by WAEC between 2015 and 2017 in Anambra state is not statistically significant.

To test this hypothesis, data were extracted from official records of students' percentage mean achievement obtained from WAEC. Emphasis on the extracted data was only on the high grade scores. This is because, it is the grade generally regarded as good grades. This is because it qualifies students for further studies and even employers of labour request for such grade. The data are represented in frequency counts according to scores by year.

Table 5h. Showing number of students that obtained high grade scores in physics in SSCE organized by WAEC in Anambra State between 2015 and 2017.

\begin{tabular}{llllllll}
\multicolumn{7}{c}{ Grades } \\
\hline States & $\mathbf{1}$ & $\mathbf{2}$ & $\mathbf{3}$ & $\mathbf{4}$ & $\mathbf{5}$ & $\mathbf{6}$ & Total \\
\hline 2015 & 76 & 52 & 570 & 380 & 650 & 1312 & 3040 \\
2016 & 66 & 156 & 1439 & 693 & 1003 & 1257 & 4614 \\
2017 & 145 & 132 & 973 & 411 & 801 & 1485 & 3947 \\
Total & 287 & 340 & 2982 & 1484 & 2454 & 4054 & 11601 \\
\hline $\mathrm{P}<0.05$ & & & & & &
\end{tabular}

$\mathrm{P}<0.05$

Summary of Chi-square table

\begin{tabular}{lllll}
\hline Total & Df & Calculated $\chi^{2}$ square & Table $\chi^{2}$ square & Decision rule \\
\hline 11601 & 10 & 365.75 & 18.307 & Reject \\
\hline
\end{tabular}

From the result on table $5 \mathrm{~h}$ and its associated chi-square summary table, the calculated $\chi^{2}(365.75)$ is greater than the table (critical) $\chi^{2}(18.307)$. Based on the values, the researchers rejected the null hypothesis and concluded that the \% mean achievement of students in physics in SSCE organized by WAEC within the years referred is statistically significant. 


\section{Discussion}

From the analysis carried out on data collected from the WAEC achievement records on students performance in physics in SSCE between 2015 and 2017, it was seen that Abia state had the lowest percentage of students' entry in physics while Imo had the highest percentage students' entry in physics in the SSCE in the zone. It was also seen that for the three years, the zonal average percentage passes in the high grade scores were greater than $50 \%$. Hence, this finding is in contradiction with that of Alaka and Obadora (2013) and Sakiyo and Badau (2013) that found a below average performance of students in the core science subjects in WASSCE.

Furthermore, the findings of the study showed that Ebonyi state has the highest percentage of $F(9)$ failure grade for the three years in the zone. This shows the fragile state of Ebonyi state; education system and that it is lagging behind others in the zone. This is consistent with the 2017 National Bureau of statistics ranking, which showed Ebonyi state be lagging behind others educationally in the zone. The position of Ebonyi state education system in the zone was further confirmed by the findings on her average percentage achievement in physics which showed that although it was above average, but it was the least in the zone. This means that Ebonyi state should buckle up to catch up with the other states in the zone. This becomes inevitable as the South east zone is generally reputed to be among the zones with advanced education system in Nigeria (NBS, 2017).

However, the implication of the significance difference found in the hypotheses tested in this study was that the achievements of students in all the states in the zone and within each states per year for the three years were not the same in physics. This further implies that some improvement and innovative approaches were adopted by the states which made them to do better than each other. Hence there were healthy competitions between states in the zone. It further showed that states were increasingly investing more resources in their annual budgets for the study of science education. This was confirmed by the highest mean percentage increase recorded each year in students percentage mean achievement in physics.

Finally, in order to sustain the tempo, states in the zones should not relent in increasing annual budgetary allocation for the study of science. State Ministries of Education should intensify the conduct of routine effective supervision of science instruction in schools as supervision plays vital role in effective reaching and learning in schools. This is very important as Sakiyo and Badau (2013) has earlier noted that Nigeria needs scientists and technologists to grease its wheel of development in science and technology which is an index of the developed nations of the world.

\section{Conclusion}

Going by the findings of this study, it was concluded that Ebonyi state should do more to catch up and even overtake other states in the zone, so as to extricate itself from being ranked as state with the least developed educational system. Furthermore, it was also concluded that despite the fact that the zone recorded mean achievement of more than average, there is need for the zone to improve her performance in physics. This will happen if more resources are committed into the study of physics, and if there is improved monitoring in school.

\section{Recommendation}

Based on the findings of this study, it is recommended as follows:

- $\quad$ States should continue to commit more resources in their annual budget for the improvement of study of physics.

- $\quad$ States should intensify supervision of physics instructional delivery in schools.

- $\quad$ Physics teachers should be exposed to regular in service training.

- $\quad$ States should engage professional qualified physics teachers to teach in their schools.

- $\quad$ Incentives to motivate hard working physics teachers should be provided by government.

\section{REFERENCES}

Ademola, A.S. Olufunke, B.O., and Amoke M. (2013). Trends in Students' Achievement in Senior Secondary School Certificate Examination (SSCE) in Chemistry, between 2008 and 2012. International Journal of Science and Research (USR), Inda online ISSN 2319-7064.

Adeyemi, T.O. (2011). A Comparative Study of Students' Academic Performance in Public Examination in Secondary Schools in Ondo and Ekiti States, Nigeria. Current Research Journal of Economic Theory. 3(2): 36-42. 2011 ISSN.

Alaka, A.A., and Obadara, O.E. (2013). Scholastic Performance of Students at West African Senior Secondary Certificate Examinations in Nigeria. Journal of Education and Social Research. Vol. 3(1) January 2013. Doi: $105901 /$ jesr. 2013 x 3n $1 \& 273$.

Alna, J.K. (2014). Importance of Science Education to National Development and Problems Militating Against its Development. Science and Education Research to Knowledge 1 (J).

Federal Republic of Nigeria (2013). National Policy on Education $6^{\text {th }}$ Edition NERDC, 3 Jibown Street Yaba Lagos Nigeria. 
Ibeh G.F, Onah G.F, Onah D.U; Umahi, A.E., Ugwuonah F.C., Nnachi, N.O., and Ekpe, J.E. (2013). Strategies to Improve Attitude of Secondary School Studentss towards Physics for Sustainable Technological Development in Abakaliki L.G.A. Ebonyi Nigeria. Journal of Sustainable Development Studies ISSN 22014268 vol. 3 No. 2, 2013, 127-136.

Mekonnen, S. (2014). Problems Challenging the Academic Performance of Physics Students in Higher Government Institutions in the Case of Arbaminch, Wolayita Sodo, Hawassa and Dilla Universities, Natural Science 6, 362-375. http://dx.doi.org/10, 4236/ns.

National Bureau of Statistic (2017). Multiple Indicator Cluster Survey (MICS). Abuja. National Bureau of statistics.

Nwankwo, M.N and Madu, B.C., (2014). Effects of Analogy Teaching Approach on Students' Conceptual Change in Physics Greener Journal of Educational Research 4(4): 119-125. http//doi.org/10.15580/wer 2014.4.0324160.

Nweke, C.O. (2021). Predictive Validity of Students' Achievement in JSSCE in Basic Science on their Achievement in SSCE in Science Subjects. Unpublished Ph.D Thesis, Faculty of Education, Ebonyi State University, Abakaliki.

Otuka, J.O.E. (1983). Problems Relating to the Development of Physics Education in Secondary Schools. Journal of the Science Teachers Association of Nigeria. 21 (2) 133-136.

Ogunleye W., and Lasis L. (2008). Increasing Women Enrolment in Physics Education. The Way Forward. Journal of Science Teachers Association of Nigeria 43 (1 and 2), 35-43.

Onah, D.U. and Ugwu, E.I. (2010). Factors which Predict Performance in Secondary School Physics in Ebonyi North Educational Zone of Ebonyi State, Nigeria. Library Advances in Applied Science Research 2010 1(3): $255-258$

Sakiyo J. and Badau, K.M. (2015). Assessment of the Trend of Secondary School Students' Academic Performance in the Sciences, Mathematics and English: Implication for the Attainment of the Millenium Development Goals in Nigeria. Advances in Social Science Research Journal - Vol. 2. No. 2 doi: 10.14738 /assrj.22.805.

West African Examination Council (2019). School Entries and Results for the core Science Subjects for the Five Southeast States (2015-2017). Yaba Lagos Nigeria. 